\title{
Research on the Curriculum of Marketing Major in Higher Education Institutions- -Based on Research-based Teaching
}

\author{
Liu Pu Huang ChunPing Ji WenJia \\ School of Economic and Management \\ Hebei University of Technology \\ TianJin, China \\ epu@sina.com; 28433676@qq.com; jiwenjiahebei@126.com
}

\begin{abstract}
Where changing social circumstances demand reform of marketing, this in turn provokes new thinking in marketing education. Therefore, research on the marketing professional curriculum is becoming more and more important. The curriculum on the basis of research-based as the interface between research, teaching and learning can give students the opportunity to experience their own behavior in the real process and develop the competences they need as researchers, which is becoming widely widespread. This study selects the 9 top universities in marketing major in China as samples to carry on the comparative analysis of their curriculums, then puts forward a new curriculum based on research-based teaching in order to provide a reference for higher education institutions to cultivate innovative marketing talents. (Abstract)
\end{abstract}

Keywords-Research-based Teaching; Marketing Major; Curriculum (key words)

\section{INTRODUCTION}

Marketing originated in the United States in the early 20th century. In China, since Jinan University in Guangzhou first opened marketing courses in 1978 to marketing major is included in the national catalog in 1992, the time of the official development of marketing just has twenty years. Although the continued improvements in marketing major enable enterprises to cultivate a large number of professional talents, it is probably fair to say that countries around the world recognize that higher education institutions (HEI) need to respond thoughtfully to the new a nd more complex political, economic, and social-cultural contexts of our times $^{[1]}$. Traditional teaching philosophy, which focused on cramming, then students accepted passively, cannot cope with current challenges. In conse quence, building an efficient and feasible training mode is imperative.

The education model of A merican research universities, originated from Humboldt principle, is a vital means to stimulate the students' awareness of innovation, exercise and develop their innovative ability ${ }^{[2]}$. The so-c alled researchbased teaching(RBT) focuses on three main goals for students: first, a deeper knowledge of a subject through an independent search of research literature and engagement with their own research question; second, the acquisition of research skills, meaning that students are able to go through the research cycle and to use research methods; and third, the development of an at titude as a resear cher, meaning that students learn to accep $t$ the insecurity of the research process $^{[3]}$. Several authors suggest that the challenges of the twenty-first century require higher education institutions to prepare students as independent thinkers, productive citizens, and future leaders ${ }^{[4]}$. And in order to be success ful in an increasingly complex world, students need to ex perience a solid liberal education. RBT, as a paradi gm for enhancing teaching and learning can facilitate learning and student development given today's complex higher education environment and the diverse needs of students.

This paper analyzes marketing major curriculums of nine HEI at the $\mathrm{c}$ ore of RBT to establish innovative talents training model and achieve the purpose of training highquality marketing professionals.

\section{THE STATUS OF RESEARCH TEACHING}

\section{A. Overseas Research}

RBT has set itself the aim of fostering the spirit of innovation and research capabilities and become a w ider trend in HEI on a global scale. America is the earlier country to carry out RBT of undergraduates in the world. During this process, most of American research universities took distinctive measures and achieved successful experience ${ }^{[5]}$. Since 1959, Harvard has established "Seminar" for freshmen, which covered many fields and involved interdisciplinary fields, aiming at cultivating students to seek scientific spirit continuously; Stanford, opened "Stanford Introduction" for new students, which did not emphasize on the systematic knowledge or comprehensive generality but stressed guidance to stimulate students' interest in the su bject and make them receive training in research methods of specific disciplines; MIT established research groups to provide research opportunities for undergraduates; University of California-Berkeley carried out "The Undergraduate Research Apprentice Program", demanding that undergraduates must have $16.7 \%$ of the credits for scientific research; Yale offered "Guiding Research" courses for students, characterizing by teaching by famous professors and the ratio of teaching and discussing being 1:2; In addition, French set up "Tr avaux dinitiative personnellle encadres" courses in college preparatory classes, requiring students to critically study on the existing outcomes under the guidance of teachers; Germany carried out "Freiarbeit" that students can choose learning contents, speed, form, location, accepted help and organizational forms freely on the condition that they finished the specified contents what are required in the syllabus; Japan set $u p$ "Comprehensive Study" courses, which specifies the learn ing time but does not set learning contents, students can choose the learning contents and forms according to their interests and hobbies. 


\section{B Domestic Research}

Curriculum in foreign universities based on RBT has more mature model and system, which is inextricably linked with the perfect market economy and canonical educational system. However, our conditions are not yet mature and cannot copy the western mode completely. Therefore, domestic HEI can attempt and explore in different ways by studying and drawing some experience from abroad.

Since 1995, Tsinghua University has carried out "Student Research Training" to undergraduates, emphasizing the practice and research integrated into teaching process; From 1999, University of Science and Technology of China ruled that those undergraduates who co mpleted a four semester credits and did well in all courses can apply to participate in scientific research and research programs established by the internal key research institutions; From 2002, Peking University began to realize the students' free elective credit system gradually, allowing students to gain achievements and credits in way of excellent papers, fruitful innovation activities, extracurricular technological outcomes; Beijing University of Aeronautics and A stronautics equipped outstanding undergraduates with mentors, thus students can access to relevant laboratory timely by mentors' specific learning plan; "Students' Innovative Training Program" of Hunan University encouraged students to eng age in initial innovative research work under the tutors' guidance. At the same time, it also established project funds, thus stimulating the enthusiasm of teachers and students to exp lore and participate in innovative projects ${ }^{[6]}$.

Although the above domestic and foreign HEI adjusted themselves actively to dif ferent degrees to pr omote the exertion of students' creative potential, the reform of marketing professional curriculum in HEI is still limited and a few studies have addressed it directly and systematically. Therefore, in this s tudy, it possessed the important theoretical and practical significance to explore further research about marketing professional curriculum on the basis of successful experience from the above HEI.

\section{DOMESTIC CURRENT SITUATION AND COMPARATIVE ANALYSIS}

\section{A Current situation}

At the macro level, the Ministry of Education has consciously shifted the train focus from basic ability to innovation and applica tion capabilities. So HEI should actively explore the training model of innovative talents, conforming to the development changes of education.

In order to comprehend the talent nurturing model of marketing in china, we decide to select the marketing of HEI at the top of the list as samples. They not only reflect the leading level of marketing curriculum design in China to some extent but also offer guidelines for other universities. To this end, we gained "Undergraduates Marketing Major Ranking" from two channels:"Ranking of marketing major of 380 Chinese universities in 2 012, http://huangwen 200301930.blog.163.com/blog/static/4848498120125161039 0756/"and "Ranking of marketing major of Chinese college in 2012-2013, http://www.nseac.com/html/261/243435.html" (Table I)

Among them, we choose universities belonging to "985 Project", such as Na nkai University, Wuhan University, Zhejiang University, Renmin University of China, Peking University and Sun Yat-sen University. Jinan University and Southwestern University of Finance and Economics which are"211 Project" and those belonging to neither"9 85 Project" nor "211 Project", for example, Shanghai University of Finance and Economics as research objects, which possess adequate information and rank the top 20 in marketing major. By analyzing their features of marketing, this study makes a significant contribution for HEI to train future innovative and creative marketing professionals.(Table II)

\section{B Comparative analysis}

From Table II, we can find that the curriculums opened in these nine HEI sharing the following features.

I. The specialized basic courses are set to guaran tee the knowledge system of marketing major.

For marketing professional, Marketing, Marketing Research, Consumer Behavior, Advertising, International marketing and so forth, they all form the foundation of discipline system and $\mathrm{k}$ nowledge structure of building marketing talents, embodying in these nin e universities. To RBT, the organic unity of the learning and discovery process of scientific truth in the process of course, or the accep ted learning and research learning, is the important means to achieve the teaching goal.

The $9 \mathrm{u}$ niversities choose the conte nt of marketing curriculum in a certain level as based to organize accepted learning and research learning, which complied with people's cognitive laws. Any reform is carried out step by step, cannot directly from one extreme to another. In the implementation of RBT, we should not ignore the key role of accepted learning at the same time. Research learning should be carried on gradually on the basis of accepted learning, thus making students grasp knowledge, develop personal potential and improve the ability of self-learning.

II. Research methods in related to marketing are opened. Although there are different courses in different universities, however, they can be achieved the goal of "teach him to fish".

RBT not only focuses on the acquisition of knowledge but pay more attention to the scientific process of obtaining knowledge. If HEI only open the courses related to existing research results, students just passively accept, self-learning ability will not get promoted, effectiveness of innovation and independence is more difficult to achieve. Therefore, it is necessary to teach students the scientific process of acquisition, pay attention to guiding students to deve lop a deeper understanding of the relation of process to result. So students experience from the forming process of the concept and inspire from the deductive process of theory, so that a systematic training of scientific research methods is came into being. Once teachers teach students how to fish, they will get fishes by themselves. "Fishing" means research methods and approa ches in marketing, such as marketing 
topics, marketing simulation experiment and marketing engineering.(Table III)

The main requirement of RBT is to cultivate students' ability of learning and study by themselves. Autonomous learning is not only the guarantee of students' developing various skills and ability in the learning process but the basic premise of their lifelong learning. Teachers teach students more knowledge less than methods, encourage their autonomous learning and guide them to explore learning rules. The opening of the four courses creates conditions for students to cultivate the ability of thought and practice by themselves.

III. HEI open some courses for improving students' professional skills and adaptive ability according to their own characteristics (Due to limited space, some are not be listed individually in Table II). For exa mple, Renmin University of China opens marketing for non- profit organizations, Industry Marketing; Peking University has some humanistic courses, such as Business Ethics, Sociology, Social Psychology and Theory of Organizations ; Marketing across Cultures, Chain Operation Management are set in Su n Yat-sen University; Southwestern University of Finance and $\mathrm{E}$ conomics opens E-marketing and competitive strategy. Meanwhile, Bank Marketing, Telecom Marketing and Auto Marketing which are career-oriented are set. The o pening of these courses, on the one hand, strengthen the purpose of RBT and meet the needs of the employers; On the other hand, can encourage students to apply what they learn and have a competitive advantage in employment.

The above analysis shows that the 9 universities effectively integrate the research learning and acce pted learning in the curriculum, thus a step by step and complementary research activities are formed. Marketing is a multi-disciplinary major, covering wide areas in s ociety, both with a strong theory and practicality. In the mutual promoted process of research learning and accepted learning, on the one hand, students' basic specialized knowledge are accumulated unceasingly, thus contributing to the improvement of learning ability; On the other hand, students' ability of innovation and practice are cultivated, thus promoting better access to knowledge acquisition and skill improvement.

\section{SUGGESTION}

By comparative analysis of the $9 \mathrm{t}$ op universities in marketing major in China, we can get the conclusion that, in those curriculums, they have reflected the characters of the problem, activity, process a nd openness of RBT to s ome extent, which is helpful to cultivate students' innovation and application. However, as this major gradually advanced and mature in our country that it necessitates the reality and urgency of its project, as well as the cultivation of this kind of talents in the present. Therefore, some suggestions are put forward to improve the current curriculum marketing major:

Firstly, we sh ould enhance the teac hing of research methods and app roaches, such as Marketing Engineering, Structural Equation Model a nd so forth. RBT focuses on introducing students to the skills required to conduct their own research activities. Students are not only given an insight into current research but are also taught to understand research processes and to initiate them themselves ${ }^{[7]}$. It means that students are able to go through the research cycle and to use research methods and a pproaches. In this way, their enthusiasm for critical enquiry, resourcefulness and creative solutions are developed.

Secondly, we cannot just emphasize research learning and lose sight of the essen tial role of specialized basic courses. Most of the HEI should be appropriate to decrease the proportion of the public basic co urses and increase the professional and experimental lessons which can highlight its merits and the requirement of the exercise cultivation. But RBT does not just mean to increase the proportion of practical and research lessons blindly and reduce the specialized basic courses. Instead, the latter is the foundation of the former. Specialized basic courses are benefit for the steady development of student's intelligence, thus create conditions for research study in turns. Practical and research cannot be carried out smoothly without specialized basic courses. Therefore, specialized basic courses cannot be denied and abandoned blindly.

Thirdly, we $m$ ust take the focus of local industry development into account so that some specific industryrelated courses of job-orientated are se t. HEI sho uld set curriculum according to the need o $\mathrm{f}$ occupation and professional standards. Only in this w ay, can the skills, abilities, and pers onal qualities typically associated with employability, such as self-management, critical analysis, creativity, solve problems, resolve conflict, make decisions, negotiate, work in teams, and wo rk cross-culturally be cultivated.

\section{CONCLUSION}

The setting of curriculum as a research topic is still of great realistic significance based on c urrent domestic education system. The c urriculum based on RBT of marketing major aims at acc elerating the construction and development of Chinese marketing major and providing society with high-level compound talents with a strong marketing capability. This study selects the 9 top universities in marketing major in $\mathrm{Ch}$ ina as samples to analyze the characteristics of their curriculums and puts forward a new curriculum based on RBT. This curriculum emphasizes on teaching research methods and approaches and cannot ignore the specialized basic courses at the same time. Meanwhile, this new curriculum should combine with the focus of local industry to set some specific industry-related courses.

\section{ACKNOWLEDGMENT}

Authors would like to thank the School of Economic and Management at the Hebei University of Technology for providing the Research Project Fund to conduct this study. No1, Research on the $t$ raining mode of innovative talents major in marketing - based on $r$ esearch-based teaching presided by $\mathrm{Li} \mathrm{Pu}$. No2, Research on the training mode of management talents who meet the needs of social adaptation ability chaired by Huang ChunPing. 


\section{REFERENCES}

[1] UNESCO. Higher Education in the Twen ty-first Century: Vision and Action: World Conference..., Paris, 5-9, October, 1998[M]. Unesco, 1998.

[2] Zhao Hong. Studybased teaching and college teaching methods reform $[\mathrm{J}]$. Journal of Higher Education, 2006, 27(2), 71-75.

[3] Hellmer J. Forschend es Lernen an $\mathrm{H}$ amburger Hochschulen-Ein Überblick über Potentiale, Schwierigkeiten und Gelingensbedingungen[J]. Huber L./J. Hellmer/F. Schneider (Hg.)(2009): Forschendes Lernen im Studium. Aktuelle Konzepte un d Erfahrungen. UniversitätsVerlagWebler, Bielefeld, 2009: 201-223.

[4] Baxter Magolda M, Teren zini P T. Learning and teaching in the 21 st century: Trends and implications for practice[J]. Higher education trends for the next century: A research agenda for student success, 1999: 20-29.

[5] Luo Mouyu. Research o $n$ research-way teaching and learning quality of university teachers [D]. Nanjing University of Aeronautics and Astronautics, 2009.

[6] Cai KeYong. Chinese education in the 21st century[M]. GuangZhou , Guangdong Higher Education Press, 2004:221-222

[7] Pawelleck A, Brendel S. Re search-based teaching and learning (RBTL)-a paradigm for en hancing teaching and learning at research universities[J]. REDU. Revista de Docencia Universitaria, 2013, 11(3): 159-172. 
TABLE I.

RANKING OF UNDERGRADUATES MARKETING MAJOR

\begin{tabular}{|c|c|c|c|c|c|}
\hline \multicolumn{3}{|c|}{$\begin{array}{l}1 \text { Ranking of marketing major for } 380 \text { Chinese universities in } \\
2012\end{array}$} & \multicolumn{3}{|c|}{2 Ranking of marketing major of Chinese college in 2012-2013 } \\
\hline $\begin{array}{c}\text { Rankin } \\
\text { g }\end{array}$ & The name of university & $\begin{array}{c}\text { Degr } \\
\text { ee }\end{array}$ & $\begin{array}{c}\text { Rankin } \\
\text { g }\end{array}$ & The name of university & Degree \\
\hline $1 *$ & Renmin University of China & $\mathrm{A}+$ & $1 *$ & Peking University & $5 \star$ \\
\hline $2 *$ & Dohua University & $\mathrm{A}+$ & $2 *$ & Renmin University of China & $5 \star$ \\
\hline $3 *$ & Dalian University of Technology & $\mathrm{A}+$ & 3 & Tsinghua University & $5 \star$ \\
\hline 4 & Zhongnan University of Economics and Law & $\mathrm{A}+$ & $4 *$ & Sun Yat-sen University & $5 \star$ \\
\hline 5 & Jilin University & $\mathrm{A}+$ & $5 *$ & Zhejiang University & $5 \star$ \\
\hline $6^{*}$ & Peking University & $\mathrm{A}+$ & $6^{*}$ & Dalian University of Technology & $5 \star$ \\
\hline 7 & Wuhan University & $\mathrm{A}+$ & $7 *$ & $\begin{array}{l}\text { Southwestern University of Finance and } \\
\text { Economics }\end{array}$ & $5 \star$ \\
\hline 8 & Nankai University & $\mathrm{A}+$ & 8 & Fudan University & $5 \star$ \\
\hline 9 & Sichuan University & $\mathrm{A}+$ & 9 & $\begin{array}{c}\text { University of International Business and } \\
\text { Economics }\end{array}$ & $5 \star$ \\
\hline $10^{*}$ & $\begin{array}{l}\text { Shanghai University of Finance and } \\
\text { Economics }\end{array}$ & $\mathrm{A}+$ & $10 *$ & Jinan University & $5 \star$ \\
\hline $11^{*}$ & Sun Yat-sen University & $\mathrm{A}+$ & $11^{*}$ & Dongbei University of Finance and Economics & $5 \star$ \\
\hline 12 & Shenzhen University & $\mathrm{A}+$ & 12 & Wuhan University of Technology & $5 \star$ \\
\hline 13 & Liaoning University & $\mathrm{A}+$ & $13^{*}$ & Dohua University & $5 \star$ \\
\hline $14^{*}$ & Jinan University & $\mathrm{A}+$ & 14 & Northeastern University & $5 \star$ \\
\hline 15 & Tianjin University of Finance and Economics & $\mathrm{A}+$ & 15 & Henan Agricultural University & $5 \star$ \\
\hline $16^{*}$ & $\begin{array}{l}\text { Southwestern University of Finance and } \\
\text { Economics }\end{array}$ & $\mathrm{A}+$ & 16 & Xi'an University of Technology & $5 \star$ \\
\hline $17 *$ & $\begin{array}{l}\text { Dongbei University of Finance and } \\
\text { Economics }\end{array}$ & $\mathrm{A}+$ & $17^{*}$ & Shanghai University of Finance and Economics & $5 \star$ \\
\hline $18^{*}$ & Zhejiang University & $\mathrm{A}+$ & 18 & BeijingJiaotongUniversity & $5 \star$ \\
\hline 19 & Huaqiao University & $\mathrm{A}+$ & 19 & Jiangxi University of Finance and Economics & $5 \star$ \\
\hline 20 & Zhongyuan University of Technology & A & 20 & Nanjing University & $5 \star$ \\
\hline
\end{tabular}

Note: “*” Denotes that schools appeared in two ranking columns 
TABLE II. COLLEGES AND TheIR RESEARCH Methods COURSES

\begin{tabular}{|c|c|c|c|}
\hline Course & Higher Education Institutions & Course & Higher Education Institutions \\
\hline \multirow{4}{*}{$\begin{array}{l}\text { Marketing } \\
\text { Topics }\end{array}$} & $\begin{array}{l}\text { Southwestern University of Finance and } \\
\text { Economics }\end{array}$ & \multirow{4}{*}{$\begin{array}{l}\text { Marketing } \\
\text { Experiment } \\
\text { Simulation }\end{array}$} & \multirow{2}{*}{$\begin{array}{c}\text { Southwestern University of Finance and } \\
\text { Economics }\end{array}$} \\
\hline & Wuhan University & & \\
\hline & Nankai University & & Renmin University of China \\
\hline & $\begin{array}{l}\text { Shanghai University of Finance and } \\
\text { Economics }\end{array}$ & & Jinan University \\
\hline \multirow{3}{*}{$\begin{array}{l}\text { Research } \\
\text { Methods }\end{array}$} & Zhejiang University & \multirow{3}{*}{$\begin{array}{l}\text { Marketing } \\
\text { Engineering }\end{array}$} & $\begin{array}{c}\text { Southwestern University of Finance and } \\
\text { Economics }\end{array}$ \\
\hline & Wuhan University & & Wuhan University \\
\hline & Sun Yat-sen University & & Renmin University of China \\
\hline
\end{tabular}

TABLE III. 9 UNIVERSITIES MARKETING PROFESSIONAL CURRICULUM

\begin{tabular}{|c|c|c|c|c|c|}
\hline & Peking University & Jinan University & $\begin{array}{l}\text { Southwestern University of } \\
\text { Finance and Economics }\end{array}$ & Zhejiang University & Wuhan University \\
\hline 1 & Market Research & Market Research & Marketing Research & Marketing Research & $\begin{array}{l}\text { Marketing } \\
\text { Research }\end{array}$ \\
\hline 2 & Marketing & Marketing & Marketing & Marketing & Marketing \\
\hline 3 & Consumer Behavior & Consumer Behavior & Consumer Behavior & Consumer Behavior & $\begin{array}{c}\text { Chinese Consumer } \\
\text { Behavior }\end{array}$ \\
\hline 4 & Advertising & Advertising & Advertising & Advertising & $\begin{array}{l}\text { Advertising } \\
\text { Management }\end{array}$ \\
\hline 5 & $\begin{array}{c}\text { International } \\
\text { Marketing }\end{array}$ & $\begin{array}{c}\text { International } \\
\text { Marketing }\end{array}$ & International Marketing & $\begin{array}{c}\text { International } \\
\text { Marketing }\end{array}$ & $\begin{array}{c}\text { International } \\
\text { Marketing }\end{array}$ \\
\hline 6 & Services Marketing & Services Marketing & Services Marketing & & Services Marketing \\
\hline 7 & Marketing Channels & Distribution Channel & $\begin{array}{l}\text { Channel Development and } \\
\text { Maintenance }\end{array}$ & & $\begin{array}{c}\text { Channel } \\
\text { Management }\end{array}$ \\
\hline 8 & $\begin{array}{c}\text { Marketing Strategy } \\
\text { Management }\end{array}$ & $\begin{array}{c}\text { Enterprise Strategy } \\
\text { Management }\end{array}$ & Strategy Management & Strategy Management & \\
\hline 9 & Retail Management & Retailing & Retail Marketing Management & & \\
\hline 10 & Brand Management & Brand Management & Brand Management & & \\
\hline 11 & $\begin{array}{c}\text { Dalrymple's Sales } \\
\text { Management }\end{array}$ & & Dalrymple's Sales Management & & \\
\hline 12 & & & Public Relations & & Public Relations \\
\hline 13 & $\begin{array}{l}\text { Logistics and Supply } \\
\text { Chain Management }\end{array}$ & $\begin{array}{l}\text { Logistics and Supply } \\
\text { Chain Management }\end{array}$ & Modern Logistics Management & & \\
\hline 14 & $\begin{array}{c}\text { Applied Multivariate } \\
\text { Statistical Analysis }\end{array}$ & Statistics & Statistics & Management Statistics & \\
\hline 15 & Electronic Commerce & Electronic Commerce & Electronic Commerce & & \\
\hline 16 & & Selling & Negotiations and sales & & \\
\hline 17 & & $\begin{array}{l}\text { Marketing Planning } \\
\text { and Practice }\end{array}$ & Marketing Planning & Marketing Planning & \\
\hline 18 & & & Marketing Topics & & Marketing Topics \\
\hline 19 & & & Marketing Engineering & & $\begin{array}{c}\text { Marketing } \\
\text { Engineering }\end{array}$ \\
\hline 20 & & & & $\begin{array}{c}\text { Research } \\
\text { Methodology for } \\
\text { Management }\end{array}$ & $\begin{array}{l}\text { Methods of } \\
\text { Marketing } \\
\text { Research }\end{array}$ \\
\hline 21 & & $\begin{array}{l}\text { Marketing Simulating } \\
\text { and Diagnosing }\end{array}$ & $\begin{array}{l}\text { Designing and Simulation of } \\
\text { Marketing Experiment }\end{array}$ & & \\
\hline
\end{tabular}


TABLE IV. (CONTINUED) 9 UNIVERSITIES MARKETING PROFESSIONAL CURRICULUM

\begin{tabular}{|c|c|c|c|c|c|}
\hline & Nankai University & $\begin{array}{l}\text { Shanghai University of } \\
\text { Finance and Economics }\end{array}$ & $\begin{array}{c}\text { Renmin University of } \\
\text { China }\end{array}$ & $\begin{array}{l}\text { Sun Yat-sen } \\
\text { University }\end{array}$ & Totle \\
\hline 1 & $\begin{array}{l}\text { Marketing Research } \\
\text { and Forecast }\end{array}$ & Marketing Research & Marketing Research & Marketing Research & 9 \\
\hline 2 & Marketing & Marketing & Marketing & Marketing & 9 \\
\hline 3 & Consumer Behavior & Consumer Behavior & Consumer Behavior & Consumer Behavior & 9 \\
\hline 4 & Advertising & Advertising & Advertising & Advertising & 9 \\
\hline 5 & $\begin{array}{l}\text { International } \\
\text { Marketing }\end{array}$ & International Marketing & International Marketing & $\begin{array}{c}\text { Globel Marketing } \\
\text { Management }\end{array}$ & 9 \\
\hline 6 & Services Marketing & Services Marketing & Services Marketing & Services Marketing & 8 \\
\hline 7 & $\begin{array}{c}\text { Channel } \\
\text { Management }\end{array}$ & & $\begin{array}{c}\text { Marketing Channels } \\
\text { Management }\end{array}$ & $\begin{array}{c}\text { Distribution Channel } \\
\text { Management }\end{array}$ & 7 \\
\hline 8 & $\begin{array}{c}\text { Marketing Strategy } \\
\text { Management }\end{array}$ & $\begin{array}{c}\text { Corporation Strategy } \\
\text { Management }\end{array}$ & & $\begin{array}{c}\text { Marketing Strategy } \\
\text { Management }\end{array}$ & 7 \\
\hline 9 & Retail Management & & Retail Business & Retail Management & 6 \\
\hline 10 & Brand Management & & $\begin{array}{c}\text { Brand Operation and } \\
\text { Management }\end{array}$ & Brand Management & 6 \\
\hline 11 & $\begin{array}{c}\text { Dalrymple's Sales } \\
\text { Management }\end{array}$ & $\begin{array}{c}\text { Dalrymple's Sales } \\
\text { Management }\end{array}$ & $\begin{array}{c}\text { Dalrymple's Sales } \\
\text { Management }\end{array}$ & $\begin{array}{c}\text { Dalrymple's Sales } \\
\text { Management }\end{array}$ & 6 \\
\hline 12 & Public Relations & Public Relations & Public Relations & Public Relations & 6 \\
\hline 13 & & & $\begin{array}{c}\text { Logistics and Supply } \\
\text { Chain Management }\end{array}$ & $\begin{array}{c}\text { Fundamental of } \\
\text { Logistics Management }\end{array}$ & 5 \\
\hline 14 & Applied Statistics & & & & 5 \\
\hline 15 & & Electronic Commerce & Electronic Commerce & & 5 \\
\hline 16 & & $\begin{array}{c}\text { Administrative and Business } \\
\text { Communication }\end{array}$ & & & 5 \\
\hline 17 & & & & & 3 \\
\hline 18 & Marketing Topics & Marketing Seminar & & & 3 \\
\hline 19 & & & Marketing Engineering & & 3 \\
\hline 20 & & & & $\begin{array}{l}\text { Marketing Research } \\
\text { Methods }\end{array}$ & 3 \\
\hline 21 & & & Marketing Model & & 3 \\
\hline
\end{tabular}

Note: there are compulsory courses and electives in the table. 